\title{
The Effect of Project Performance to Satisfaction of The Project Owner
}

\author{
Miftahul Huda \\ Lecturer of Civil Engineering Department Faculty of Engineering, \\ University of WiajayaKusuma Surabaya \\ ${ }^{1}$ Email ;miftah@yahoo.ac.id
}

\begin{abstract}
One measure of contractor company quality is how far the performance of the company can give satisfaction to the project owner. This study aims to analyze the factors of contractor performance that affect the satisfaction of project owners. The study was conducted in Surabaya City Indonesia involving all Heads and Staffs Department of Surabaya City Government as respondents. The research instrument used a Likert scale questionnaire (1-5). Methods of data collection using purposive and proportional sampling.Data analysis using structural equation modeling with the help of SmartPLS software. The results of this study conclude that all analyzed factors are composed of : project performance (X1), project products (X2), project services (X3), green construction (X4), health and safety work (X5) have a positive and significant impact on project owner satisfaction (Y).
\end{abstract}

Keywords ; performance, contractor, satisfaction, project owner

\section{INTRODUCTION}

Customer satisfaction has become a central concept in business and management discourse (Tjiptono\& Chandra, 2005) [1]. Customers generally expect products in the form of goods or services that they consume acceptable and enjoyed with good or satisfactory service (Assauri, 2003) [2]. Similarly in the construction services industry, the importance of customer satisfaction (project owner) and orientation to the project owner has grown due to the tightness of business competition. As a service provider, in this case the contractor must work as much as possible to satisfy the project owner who acts as a customer. In the past, performance in the field of construction has been measured by cost, time, and quality factors or it can also be called a triple constraint. From the "triple constraint", a project is considered successful if the project is delivered or completed in a timely manner at the right price and high quality (Agsarini\&Wiguna, 2015) [3]. However, research in the case of the satisfaction of users of construction services (project owners) is still small and rarely done.

In the world of construction services, project owner satisfaction can be identified with project performance (Wieke et al., 2012) [4]. The higher the project performance the more satisfied the project owner. Some of the previous studies that took the theme of project performance were related to safety and health (Wieke et al., 2012) [4] or related to the environment (green construction) as investigated by Huda et al, (2013) [5] which examines important factors affecting the implementation of green constructin in the pre-construction, construction and post-construction phases. All parties agree that the problem of green construction is a global issue that must be realized in every country and become the focus of attention of stakeholders in the world of construction (Harimurti, 2008; Colliver, 2009) [6] [7].

So far in the previous research, to measure customer satisfaction conducted in Indonesia more oriented to the object of research services such as services, among others; on banking services (Wijayanti, 2008: Indra\&Gunarsih, 2006) [8] [9], hospital or health services (Wiyono, 2007; Praptiwi, 2009, Wijayanti, 2009; Prasetyo, 2008) [10] [11] 8] [12] Telkomsel or telecommunication services (Hadiati\&Ruci, 2009), transport services (Manullang, 2008; Mutaqin, 2006; Widiyartie, 2007; Fahmi, 2009; Chairunnisa, 2008) [13] [14] [15] [16] [17], and educational services (Munawaroh, 2005; Wang \& Shieh, 2006; Natalisa, 2007) [18] [19] [20]. While research conducted on the object of construction services at both the national and international levels is relatively small. Therefore research related to the satisfaction of the owner of the construction project becomes very important and necessary to be implemented.

\section{MATERIALS\& METHODS}

\section{A. Data and research instrument}

The research instrument is a questionnaire using Likert scale (1-5). Data collected from Surabaya City Government Agency with purposive sampling and proportional sampling technique. The number of respondents and questionnaires are distributed as many as 125 respondents. Respondents who answered and returned the questionnaire were 87 respondents and deserve the analysis of 81 respondents' answers. The results of the complete data collection are shown in Table 1. 
TABLE 1. Number of Questionnaires Distributed to Respondents

\begin{tabular}{|c|l|c|c|c|}
\hline \multirow{2}{*}{ No } & \multirow{2}{*}{ Surabaya City Government Agencies (Department) } & \multicolumn{3}{|c|}{ Number of Questionnaires } \\
\cline { 3 - 5 } & & Sent & Back & Eligible \\
\hline 1 & Department ofCiptaKarya\& Tata Ruang & 15 & 10 & 9 \\
\hline 2 & Department ofBina Program & 15 & 11 & 10 \\
\hline 3 & Department ofBuilding \& City Management, & 15 & 15 & 14 \\
\hline 4 & Department ofPublic Works of Bina Marga, & 15 & 14 & 14 \\
\hline 5 & Department of Education & 5 & 2 & 2 \\
\hline 6 & Department of Public Health & 5 & 5 & 4 \\
\hline 7 & Department ofTransportation & 5 & 3 & 3 \\
\hline 8 & Department ofCulture \& Tourism & 5 & 1 & 0 \\
\hline 9 & Department ofYouth \& Sports & 5 & 2 & 2 \\
\hline 10 & Department of Trade \& Industry & 5 & 4 & 4 \\
\hline 11 & Department of Agriculture & 5 & 1 & 1 \\
\hline 12 & Department ofCleanliness and Gardening & 5 & 5 & 5 \\
\hline 13 & Department ofFire Service & 5 & 0 & 0 \\
\hline 14 & Department ofRevenue \& Financial Management & 5 & 5 & 4 \\
\hline 15 & Department ofCommunications \& Informatics & 5 & 5 & 5 \\
\hline 16 & Department ofKoperasi\& UMKM & 5 & 2 & 1 \\
\hline & & 125 & 87 & 81 \\
\hline
\end{tabular}

Source : Secondary data

\section{B. Modeling}

The research variables are five independent variables and one dependent variable. The influence of independent variables and dependent variables is based on theoretical and empirical studies of some previous research results: Agsarini\&Wiguna (2015) [3]; Huda \&Wibowo (2013) [21]; Omran et al. (2012) [22]; Sumaga (2013) [23], Idrus and Sodangi (2011) [24]; Colliver et al., (2009) [7]; Devia\& Huda, (2012) [25]; Wieke et al., (2012) [4] and Agsarini\&Wiguna (2015) [3].

Research results from Agsarini\&Wiguna (2015) [3] ; Huda \&Wibowo (2013) [21]; Omran et al. (2012) [22], concludes that the performance of a construction project is said to be good and can give satisfaction to the project owner if the project is successful in three things: low cost, high quality and timely completion. The result study of Sumaga (2013) [23] and Idrus\&Sodangi (2011) [24] concluded that project construction products and contractor service quality can satisfy project owners. Huda et al. (2013) [5] and Devia\& Huda (2012) [25] recommend the satisfaction of the project owner if the project is carried out with care for the environment (green construction). Wieke et al. (2012) [4] in his study concluded that simultaneously and partially the occupational health and safety work factors in the implementation of a project can provide satisfaction to the project owner.

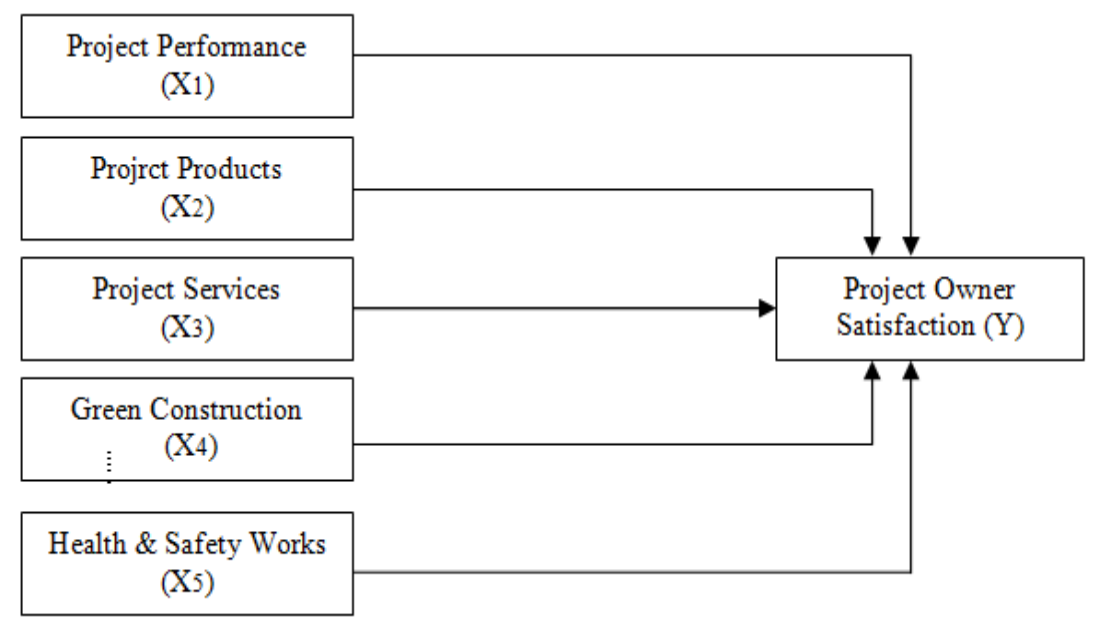

Figure 1. Research Model Framework 


\section{Variable Definitions and Indicators}

1) Project Performance (X1) :is the ability of the contractor to carry out the construction work in accordance with the construction work contract agreed with the project owner. The project performance variable is formed on 3 indicators adapted from Agsarini\&Wiguna (2015) [3], Huda \&Wibowo (2013) [21]; Omran et al., (2012) [22], consists of indicators: (a) cost of construction works (X11), (b) time of execution of work (X12) and (c) quality of work (X13).

2) Project Products (X2): is the end result of the development process from planning, engineering, auction and construction of construction projects undertaken by the contractor in accordance with the contract of work agreed upon by each party. This construction project product variable is a global dimension and has at least 7 indicator elements adopted from Sumaga (2013) [23] and Idrus\&Sodangi (2011) [24], which consists of indicators: (a) performance, (X21), (b) durability (X22), (c) privileges (X23), (d) reliability, (X24), (e) consistency (X25), (f) austhetic (X26) and (g) conformance (X27)

3) Project Services (X3): is the ability of construction service companies to provide services to users of project owners in all aspects, whether written or implied, in morally or materially. The service variable of the popular service concept construction service concept, ServQual stated that the service quality has 9 dimensions (indicator), which is adopted from Parasuraman in Sumaga (2013) [23] and Idrus\&Sodangi (2011) [24], which consists of indicators: (a) reliabilty (X31), (b) responsiveness (X32), (c) assurance (X33), (d) empathy (X34), (e) tangible (X35), (f) understanding (X36), (g) competence (X37), (h) credibility (X38) and (i) communication (X39)

4) Green construction (X4): The technology and techniques used by contractors in the construction of projectoriented construction projects taking into account the energy, pollution, water, air, materials, equipment have an impact or risk to the environment. This green construction variable is a global issue and has at least 5 indicator elements adopted from Colliver et al., (2009) [7]; Huda et al. (2013) [5] and based on Devia\& Huda's research (2012) [25] which consists of indicators: (a) technology (X41), (b) project cycle (X42), (c) energy saving (X43), (d) pollution (X44), (e) material (X45) and (f) efficiency (X46).

5) Work Safety and Health, (X5) : Involvement and active role of the management of contractor companies in formulating programs, shaping culture and realizing safety and health in the construction project environment, accompanied by a high commitment to realize the health and safety of the project environment during the project. This construction and occupational safety variable is a service provider's competency dimension and has at least 5 indicator elements adopted from Wieke et al.namely : (a) top management commitments (X51), (b) rules and procedures (X52), (c) communication (X53), (d) employee competence (X54), (e) ) worker involvement (X55) and (f) work environment (X56).

6) Represents the totality of the project owner's expectations in accordance with the totality of the contractor's work. Based on previous research results : Agsarini\&Wiguna(2015)[3] ; Idrus\&Sodangi (2011) [24] the satisfaction of contractor owners has indicator: (a) total project cost (Y1), (b) total project implementation (Y2), (c) total project completion time (Y3) and (d) total quality project (Y4).

\section{Data Analysis Technique and Model Test}

Descriptive analysis is used to describe the characteristics of respondents and also the responses of respondents. Descriptive analysis is done with the help of computer software SPSS. Similarly, validity test and tool reliability. The measuring tool is valid if the Product Moment correlation coefficient between the item score and the total score is significant ( $\mathrm{p}$-value / sig value $<\alpha=0.05$ ). Reliability testing is done by calculating Alpha Cronbach $(\alpha)$ value, if Cronbach Alpha value $(\alpha)$ is greater than 0.60 then research data is considered good enough and reliable to be used as input in data analysis process to test the research hypothesis (Maholtra, 2004) [26].

The results obtained that the value of cornbach alpha from each research variable $>0,6$. This means that each research variable has met the requirements of cornbach alpha value, so it can be concluded that all variables have a high level of internal consistency reliability. Similarly, based on the results obtained that the value of composite reliability of all research variables $>0,7$. These results indicate that each variable has met the composite reliability so it can be concluded that the overall variable has a high level of internal consistency reliability.

The model analysis used in this research is Structural Equation Modeling (SEM) with the help of SmartPLS software. The results of the model analysis can be seen in Figure 2 and Figure 3. Figure 2 shows that the loading factor estimation result is the coefficient generated from the evaluation of confirmatory factor analysis for the measurement model. Factor loading is used to assess the suitability, conformity or unidimensionality of the dimensions in forming a factor. The estimated load factor values are obtained together with the result of the loading factor estimation for each factor variable of the indicators. Figure 2 also shows the path coefficient value between the latent variables. Figure 3 shows the amount of t-value that will be used as a reference for hypothesis analysis. The value of coefficient and t-value can be seen in Table 2 . 


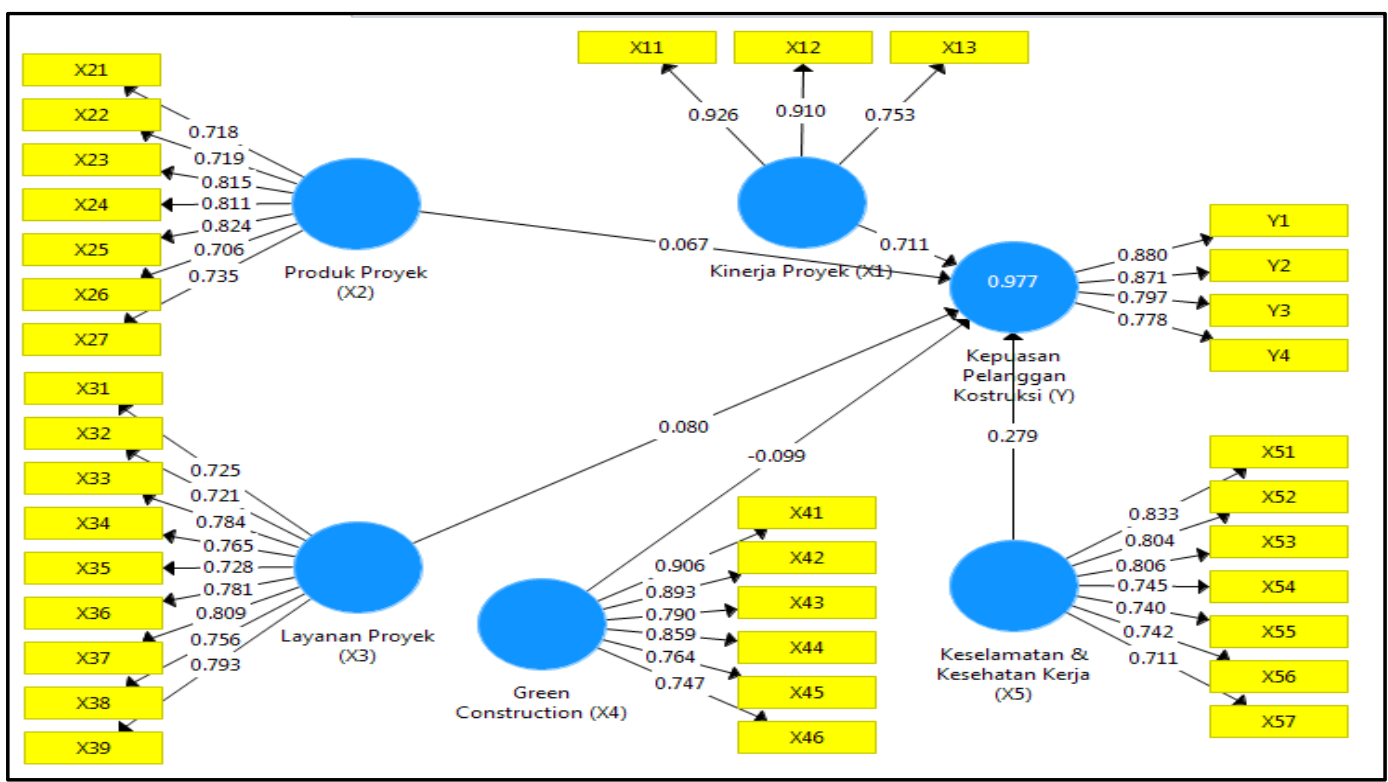

Figure 2. Loading Factor analysis with SmartPLS

A summary of the results of hypothesis testing is shown in Figure 3

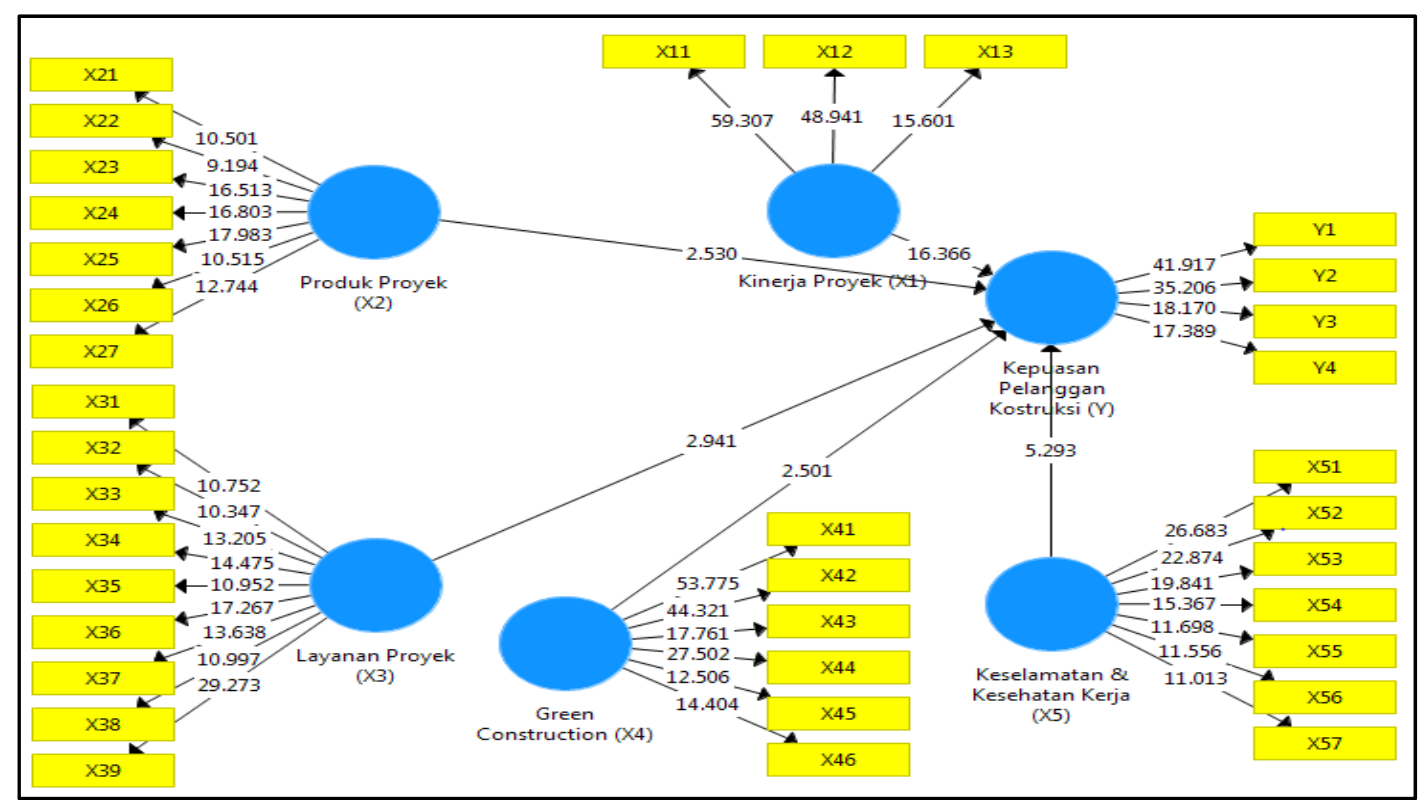

Figure 3.t-Value analysis with SmartPLS

TABLE II. Influence between Latent Variables

\begin{tabular}{|l|l|c|c|c|}
\hline \multicolumn{1}{|c|}{ Independent Variable } & \multicolumn{1}{|c|}{ Dependent Variable } & $\begin{array}{c}\text { Path } \\
\text { Coefficient }\end{array}$ & $\begin{array}{c}\mathrm{t}- \\
\text { value }\end{array}$ & $\begin{array}{c}\text { criteria t- } \\
\text { value>t-tabel } \\
=1,96\end{array}$ \\
\hline Project Performance (X1) & Project Owner Satisfaction (Y) & 0,711 & 16,366 & Significant \\
\hline Project Products (X2) & Project Owner Satisfaction (Y) & 0,067 & 2,530 & Significant \\
\hline Project Services (X3) & Project Owner Satisfaction (Y) & 0,080 & 2,941 & Significant \\
\hline Green Construction (X4) & Project Owner Satisfaction (Y) & 0,099 & 2,501 & Significant \\
\hline Work Safety and Health (X5) & Project Owner Satisfaction (Y) & 0,279 & 5,239 & Significant \\
\hline
\end{tabular}

Source: SmartPLS Results 
Hypothesis testing is done by comparing t-count value of each latent variable with t-table $(1,96)$, that is said significant if $t$-value latent variable is bigger than $t$-table ( $t$-value $>1,96)$. Table 2 shows that the $t$-value of all variables $>1.96$. Meaning all variables: Project performance (X1), Project products (X2), Project services (X3), Green construction (X4) and Work Safety \&Health (X5) are stated to have a positive and significant impact on project owner satisfaction (customer).

TABLE III. Determination Coefficient (R2)

\begin{tabular}{|c|c|c|}
\hline Latent Variable & $\begin{array}{c}\text { Squared Multiple } \\
\text { Correlation }\left(\mathrm{R}^{2}\right)\end{array}$ & Remarks \\
\hline Variable (X1 to X5) & 0,9753 & $\begin{array}{l}\text { The contribution of independent variable (X1 to X5) } \\
\text { to project owner satisfaction (Y) is 97,53\%. }\end{array}$ \\
\hline
\end{tabular}

Source: SmartPLS Results

Based on the data presented in Table 3, it can be seen that the R-Square value for the customer satisfaction of construction (project owner) is 0.9753 . These results explain that the percentage of owner satisfaction can be explained by the research variable of 97.53 percent. While the remaining 2.47 percent is explained by other variables.

\section{RESULT AND DISCUSSION}

Effect of Project Performance: The project performance is the ability of the contractor to carry out construction work in accordance with the construction work contract. Project performance consists of cost, time and quality indicators. If the lower the project cost, the faster the implementation time and the better quality of the work, the better the project performance and the more satisfying the project owner. The results show that project performance has a positive and significant effect on project owner satisfaction. The findings of this study support the results research of :Agsarini\&Wiguna (2015) [3], Huda \&Wibowo (2013) [21]; Omran et al., (2012) [22].

Effect of Project Product: The project product is the end result of the development process from planning, engineering, auction and construction of construction projects undertaken by the contractor. The project product consists of aspects; performance, durability, privilege, reliability, consistency, austhetic and conformance. The results show that the project product has a positive and significant effect on the satisfaction of the project owner. This means that the higher the value of project products, project owner satisfaction will be higher. The findings of this study support the results research of :Sumaga (2013) [23] and Idrus\&Sodangi (2011) [24].

Effect of Project Services: The project services are the ability of contractor companies to provide services to project owners in all aspects. Project service variables conform to the popular service quality concept. ServQual states that service quality has indicators that consist of: reliability, responsiveness, assurance, empathy, tangible, understanding, competence, credibility and communication. The results of this study indicate that project services have a positive and significant impact on project owner satisfaction. This means that the higher the level of project services, the project owner's satisfaction will increase. The findings of this study support the Sumaga study (2013) [23] and Idrus\&Sodangi (2011) [24].

Effect of Green Constructionl:The green construction is the technology and techniques used by contractors in the construction of construction projects oriented to the project cycle by considering energy, pollution, water, air, materials, equipment that have an impact or risk to the environment. Green construction aspects of the construction project is a global issue and has at least five elements of the indicator consisting of indicators: technology, project cycle, energy saving, pollution, material and efficiency. The results showed that green consruction gave positive and significant influence to project owner's satisfaction. This means that the more concerned the contractor to the project environment, the project owner's satisfaction is increasing. The findings of this study support the results of a study by Colliver et al. (2009) [7]; Huda et al. (2013) [5] and based on research by Devia\& Huda (2012) [25].

Effect of Health\& Safety Works : The involvement and active role of the management of contractor companies in formulating programs, shaping culture and realizing kelamatan and occupational health in the construction project environment, accompanied by high commitment to realize the health and safety of project environment during the project. This construction and health \& safety works variable is a contractor's competency dimension consisting of 5 indicators elements, namely: top management commitment, rules and procedures, communication, worker competence, worker involvement and work environment. The results showed that health and safety work have positive and significant impact to the project owner's satisfaction. This finding is consistent with the results of research by Wieke et al. (2012)[4] and Huda \&Wibowo (2013)[21]. The better the contractor's health and safety management the more satisfying the project owner. 


\section{CONCLUSION}

To improve the satisfaction of the project owner or the construction customer or the user of the knoven service, the contractor company in Indonesia should perform performance improvement in several ways: project performance, project products, project services, green construction project implementation, health and safety during project implementation takes place. The results of this study are suggested to be developed by extending the location and respondents research.

\section{REFERENCES}

[1] Tjiptono, Fandidan Gregorius Candra, Service, Quality and Satisfaction,Yogyakarta:Andi Offset.2005.

[2] Assauri, Sofjan, Customer Service Yang BaikLandasanPencapaian Customer Satisfaction, Jakarta: Usahawan No. 01 TH. XXXII, Januari, hal. 25-30. 2003

[3] Agsarini, I. Wiguna, I.P.A. PengaruhFaktorKondisiProyekterhadapKinerjaProyekKonstruksi. Prosiding Seminar nasionalManajemenTeknologi XXII. Program Studi MM-ITS. 2015

[4] Wieke Y.C., Ludfi, D., Armanu, T., PengaruhBuudayaKeselamatandanKesehatanKerja (K3) TerhadapKinerjaProyekKonstruksi. JurnalRekayasaSipil, Vo. 6, No. 1 (2012), hal. 83-95. 2012

[5] Huda, M. Rini, T.S. Paing, J. Purwito, A. Analysis of Important Factors Evaluation Criteria for Green Building. The International Journal Of Engineering And Science (IJES). ISSN (e): 2319 - 1813ISSN (p): 2319 - 1805. 2013

[6] Harimurti, Putu. G,.Green Construction, http://putuhari.wordpress.com/ green-construction/ (21 Agustus 2017). 2008

[7] Colliver Rosemary A., Jason R. Busch, \& Janet F. Jacobs. Tax and Financial Incentives for Green Building, Los Angeles Lawyer, Vol 20, No 15. 2009

[8] Wijayanti. StrategiMeningkatkanLoyalitasMelaluiKepuasanPelanggan (StudiKasusProdukKartuSelulerPrabayarmentari-Indosat Wilayah Semarang), Program Studi Magister Manajemen, UniversitasDiponegoro Semarang. 2008

[9] Indra D.A., Gunarsih I., PengaruhKualitasPelayananTerhadapKepuasanNasabahKreditPerorangandanKelompok : StudiKasusuPada BPR Bank PasarKabupatenKaranganyar, Program PascaSarjanaUniversitasMuhammadiyah Surakarta. 2006.

[10] Wiyono A.S., Chandrarin G., 2007., StudiTentangKualitasPelayanandanKepuasanKonsumen di RumahSakit Islam ManisrenggoKlaten., Program Magister ManajemenUniversitasMuhammadiyah, Surakarta. 2007.

[11] Praptiwi A., PengelolaanKepuasanPelangganDalampelayananKesehatan, MateriPelatihandan Workshop ManajemenKeperawatan di RSUD “45” Kuningan, Jawa Barat padatanggal 13 Mei 2009.

[12] Prasetya, N.A., Analisa Tingkat KepuasanPasienRawatJalanTerhadapKualitasPelayananInformasiObatApotikInstalasiFarmasiRumahSakitUmum Daerah Dr. Muwardi Surakarta, FakultasFarmasi, UniversitasMuhammadiyah, Surakarta. 2008.

[13] Manullang I., PengaruhKualitaspelayananTerhadapKepuasanPelangganJasapenerbangan PT. Garuda Indonesia Ailines di BandaraPolonia Medan, Thesis Program PascaSarjanaUniversitas Sumatera Utara, Medan. 2008.

[14] Mutaqin, A., PengaruhKualitasPelayanandanFasilitasTerhadapKepuasanPelanggan Bus PO. Timbul Jaya di Wonogiri., Thesis Program PascaSarjana (S-2) UniversitasDiponegoro, Semarang. 2006.

[15] Widyartie., L., AnalisisHubungan Tingkat PelayanandenganTarifPelayananJasaPenumpangPesawatUdara (PJP2U) Domistik di Bandar UdaraInternasionalSoekarno Hatta Jakarta. Thesis Program PascaSarjanan (S-2) UPN Jakarta. 2007.

[16] Fahmi H.A., AnalisisPengaruhKualitasPelayananTerhadapKepuasanPelangganPada Perusahaan Transportasi Garuda Indonesia Airways di Jakarta. FakultasEkonomi UPN Veteran, Jakarta. 2009

[17] Chairunnisa.HubunganKinerjaOrganisasidanKualitasPelayanan Trans Jakarta-Busway Dengan KepuasanPelangganPenggunaJasa Trans Jakarta-Busway ( StudiKasus : Pada Trans Jakarta-Busway Koridor IV PuloGadungDukuhAtas Jakarta), Program StudiIlmuAdminitrasi Negara (S-1), UniversitasDiponegoro, Semarang. 2008.

[18] Munawaroh M., AnalisaPengaruhKualitasJasaTerhadapKepuasanPadaIndustriPendidikan di Yogyakarta, JurnalSiasatBisnisEdisi,UniversitasMuhammadiyah Yogyakarta, Vol. 2, No. 5, Tahun. 2005, hal. 119-134. 2005

[19] Wang I.M., Shieh C.J., The Relationship Between Service Quality and Customer Satisfaction : The Example of CJCU Library, Journal of Infortamtuian and Optimization Sciences, Vo. 27 (2006), No. 1, pp. 193-209. 2006

[20] Natalisa D., Survey KepuasanPelanggan Program Studi Magister ManajemenUniversitasSriwijaya, JurnalManajemen\&BisnisSriwijaya Vol. 5, No 9 Juni 2007, hal 83-94. 2007.

[21] Huda, M. \&Wibowo, M.A., Strategies to Increase Performance and Sustainability of Construction Services Company in East Java Indonesia, Journal of Basic and Applied Scientific Research,Vol. 3, No. 6, pp. 741-747. 2013.

[22] Omran, A., Abdalrahman, S., \&Pakir, A. K. Project Performance in Sudan Construction Industry : A Case Study. Global Journal of Accounting and Economic Reseacrh. 2012.

[23] Sumaga, A.U. AnalisaKepuasanPenggunaJasaTerhadapPenerapanRekayasaKonstruksiProfesionalRuko di KawasanBussiness Park Kota Gorontalo. JurnalIlmiah Media Engineering Vol.3, No. 1 pp.6-13. 2013.

[24] Idrus, B.A and, Sodangi, M, Framework for evaluating quality performance of contractor in Nigeria. International journal of Civil and Environmental Engineering, Vol (10), No.01, 2011.

[25] Devia, S. Huda, M. 2012. IdentifikasiFaktor-FaktorPentingDalamImplementasiBangunan Ramah LingkunganPadaProyekKonstruksi di Kota Surabaya. Skripsi S-1 Program StudiTeknikSipil, FakultasTeknik, UniversitasWijayaKusuma Surabaya. 2012.

[26] Maholtra, Naresh K., Marketing Research, Fifth Edition, Prentice-Hall Inc., New York. 2008 